\title{
一般演題 (3)
}

\section{臨床試験における欠測例の取り扱いについて}

\author{
斧田大公望*
}

欠測值問題は, いいふるされて，なおかつ，新しい。 薬効評価にかぎらず, 臨床試験結果の解析にあたり,つ ねに，脱落・中断拈よび欠測例の取り扱いの困難さに当 面する。

適用除外 (注1) を含む脱落，ならびに，試験中断の認 定は担当医師の専権に属すべきであるが，リウマチなど 慢性疾患の場合，それが当初適用例の30\%台に至ること むある。治療方式を比較するとき, 弱い方に脱落が多く なりがちなので結果が有利に, 強い方には比較的に脱落 までにいたらず，不利に働くことが指摘されている1,2) だから，脱落例がすべて悪い経過をとると仮定したらと の見方も生じよらが，测定済データだけの場合とくらべ て，真の差がないときは緟密化が保証されても（第 1 種 - $\alpha$ 危険率の精度アップ), 一方，真の差があるときは かえって誤る割合を多くしてしまう（第 2 種・ $\beta$ 危険制 の精度ダウン）ことになりかねない.

実際には多く，対照群をおき二重盲検法に従っている など，対象繰り入れが無作為化されている場合には，脱 落理由の徹底した吟味を要するとともに, その発生が確 率的であるかどうか，群間独立性検定が試みられてい る.しかし，脱落・中断が副作用によるときには，安全 性検討の際に, 改めて比較対象に追加すべきことはいう までもない.

欠測の一番の問題は, はじめの症例構成の無作為性,

* 立教大学社会学部

（注1）例えば, 腹部鎮氫剤の試験において, 投薬後 に胃癌と確定診断された症例の場合.

（注2）第74回日本外科学会総会・胃癌 $(N)$ 演題230発 表，3/27,'74. および，伊フローレンスでの 第11回国際癌学会で口演, 10/20～26,'74. 試 験結果・考按は, 癌と化学療法, Vol. 1, No.3, 21-30, July,'74に掲載.
つまり, 対象間の均質性をゆがめてしまうことにある. 統計学者の側からも, 実験計画法の見地にたって, 関係 諸因子・水準から欠測值を推定し追補する方策が提案さ れている3,4)とはいえ, 一般式は示せても, いざ具体的に どうするか, 再現性が期待できる品質管理試験とは異な って, 臨床試験時における欠測值補充はままならない.

解析は得られたデータのみが頼りとなるが, 主治療で ある制癌剤投与時の副作用防止効果をフォローしたケー スを通じ，欠測に対処した一方法を提示してみたい.

この試験は, 切除後の胃癌患者を対象に, Mitomycin (MMC) 1 回量 $4 \mathrm{mg} 5$ 週間にわたり総量 $40 \mathrm{mg}$ 静注す る期間, ブドウ糖・ビタミン剂など基礎治療薬のみの群 (Control 群) と, それに Glutathion (GSH) 600mg を 付加した群 (GSH群)における6 週間の副作用および諸 検查值の推移を比較したもの(注2)（図 1).ただし，疾 患の性質から剂型を同一にした完全二重盲検方式にはよ らず，あらかじめの無作為配置表に従い患者の到着順に 処置を振り分け, 回収後, 処置部分を隠伏したコピーを

I 対 象

胃癌患者 イ.治療切除または非治瘾切除例 口肉眼的進行度 $I \sim \mathrm{N}$

II投与方法 八:MMC 1 回量 $4 \mathrm{mg}$ を間歇的に棇量 $40 \mathrm{mg}$ 静注する例 I 群 CONTROL群
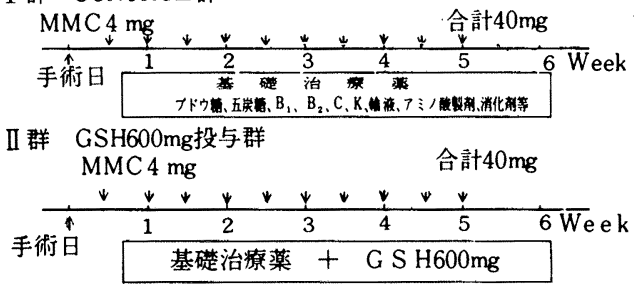

臨床計画

図1 臨床計画 


\begin{tabular}{|c|c|c|c|c|c|}
\hline & 適 & 用 & 脱 & 落 & 有 \\
\hline CONTROL 群 & & 225 & & 51 & 174 \\
\hline G S H 群 & & 238 & & 65 & 173 \\
\hline 計 & & 463 & & 116 & 347 \\
\hline
\end{tabular}

図 2 適用症例と脱落

適用症例の等分性の検定

$$
\chi_{0}{ }^{2}=0.3650<3.841=\chi_{1}{ }^{2}(05) \therefore N . S .
$$

適用症例につき，脱落・有効の群間独立性の検定

$$
\chi_{0}{ }^{2}=1.3286<3.841=\chi_{1}^{2}(0.5) \therefore \text { N.S }
$$

\begin{tabular}{c|r|r|r}
\hline & $\begin{array}{c}\text { CONTROL } \\
\text { 群 }\end{array}$ & G S H 群 & 計 \\
\hline 術 前 状 態 & 1 & 2 & 3 \\
手 術 関 係 & 3 & 7 & 10 \\
MMC 投与関係 & 39 & 48 & 87 \\
G S H 投与関係 & 5 & 7 & 12 \\
D A T A 不足 & 3 & 1 & 4 \\
計 & 51 & 65 & 116 \\
\hline
\end{tabular}

図 3 脱落症例内訳

代表医師団がダブル・チェックした。

全国63施設での適用例は計 463 例，その等分性，およ び，脱落認定例116例，分析有効例347例に拈ける群間独 立性いずれも保証され（図 2)，脱落理由についても(汹 3 )，また，属性・病態 32 項目に関しても群間差は $5 \%$ 有意には至らず，対像の均質性が認められた。

試験目的からいって検定事項は, 通常の薬効評価のよ らに投薬後一定期間の治瘾率が問題となるのではなく, 2 群のらちどちらが，所定期間中，異常を示さず主治療 が継続しえたかどうかがあげられる。薬効検定で, 時間 経過を追求する場合，ふつう，治痖率の累計を算定して Kolmogorov-Smirnov Test が試みられるけれども，今 回の場合は, まず中断例, それも副作用による中断の群 間比較が対象となり,Fisher の直接 (両側) 確率計算法 を援用した（図 4, 図 5 )。

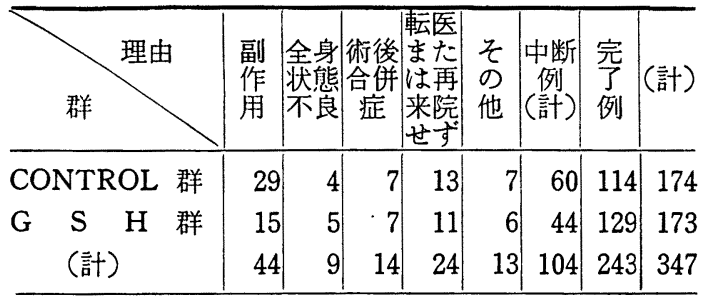

图 4 MMC 中断理由内訳

\begin{tabular}{|c|c|c|c|}
\hline & 中断例 & 完了例 & 計 \\
\hline CONTROL群 & 29 & 114 & 143 \\
\hline G S H 群 & 15 & 129 & 144 \\
\hline ( 計) & 44 & 243 & 287 \\
\hline
\end{tabular}

${ }^{*}$ Sum $=0.0223^{*}<0.05$

$\chi_{0}{ }^{2}=5.3771 *>3.8415=\chi_{1}^{2}(0.05)$

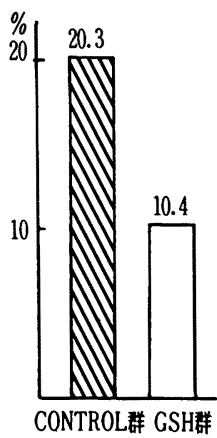

図 5 副作用の発現による MMC 中断例

次に，中断にまでいたらなかったものの，諸検査值で 陵床上，異常化した症例につき，経時的に吟味すること にした，一例として，白血球数 (WBC) の場合, 每週 1 回計 6 回測定されたが，週を追って中断例がふえると ともに, 欠測例も增加しつつけけ，異常化率算出の母数と

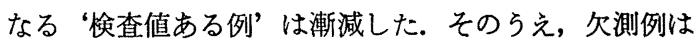
逐次加わったのではなく，ある個体例に㨟いて，第 1 週 - 第 4 週は測定，第 2 週と第 3 週は欠測といったように 出入がはげしかった. したがって, 各週時点の中断, 欠 測それぞれの発現に群間差が有意でないことを確かめた のち, 6 回の群別異常化率の大小比較対（つい）を相互 に独立したものとみなして，あたかも， match-play のよ らに正負の符号化したうえ Sign-Test を適用した（眓 $6)$.

ここでは，欠测に対処するのに，2 群比較を独立対と ‘して Sign-Test したが，7対以上であれば，異常化浮 の差の大小も加味した Sign-Ranked Test も可能とな る. 一般には, 6 対以下を含めて, 異常化の有無は 2 水

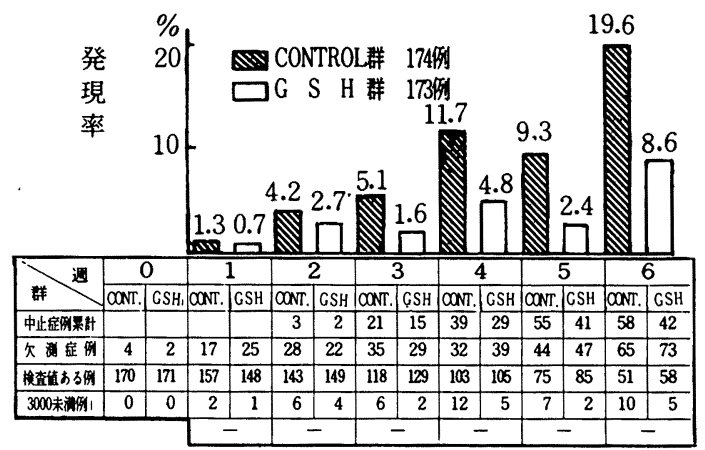

( SignTest) $P_{o}=\sum_{x=0}^{0} \quad(\stackrel{6}{x}) \frac{1}{2^{6}} \times 2=0.03125^{*}<0.05$ 図 6 WBC 異常値発現頻度 (全例) 
準だから, 繰り返し数 (例数) 不揃いの場合における, 群と経時を 2 つ因子とした $2 \times \mathrm{r} \times \mathrm{C}$ 表での Fisher 角 変換法, または, 田口の度数法による分散分析も試みら れることになる.

\section{文献}

1）砂原茂一：私達は何を根拠に薬をえらぶべきか. 日
本医事新報, $2179: 3-10$ (1966).

2 ) 砂原茂一：新薬開発における臨床実験の意義. 応用 薬理, 1(2): 89-96 (1967).

3）林知已夫 : MHS にあらわれる統計的問題. 日本臨 床, 29(9): 28-31 (1971).

4) 林知已夫 : 医学方面に打ける統計的方法の使い力に ついて. 日本公息衛生学雑誌, 20(2) : 55-59(1973). 